\title{
Typha Latifolia L. Grown in Carrying Petroleum Secondary Effluent Supply Nutrients Enhance for Biomass Growth and Phytoremediation of Heavy Metals and TPH
}

\section{Anwar Ahmad ( $\sim$ anwarak218@yahoo.co.uk)}

University of Nizwa Faculty of Engineering and Architecture https://orcid.org/0000-0003-4108-1276

\section{Research Article}

Keywords: Phytoremediation, transfer index, enrichment coefficient, heavy metals, TPH, petroleum secondary effluent, T. latifolia $\mathrm{L}$.

Posted Date: April 26th, 2021

DOI: https://doi.org/10.21203/rs.3.rs-329599/v1

License: (c) (i) This work is licensed under a Creative Commons Attribution 4.0 International License. Read Full License 


\section{Abstract}

Phytoremediation is an innovative tool which can be used for the treatment of industrial and agricultural wastewater. Typha latifolia L. (T. latifolia L) is an aquatic plant which grows on petroleum secondary effluent (PSE) containing metals like cadmium (Cd), cobalt (Co), manganese (Mn) and TPH (total petroleum hydrocarbon). The growth performance in biomass, nutrient concentrations and heavy metals in parts of the T. latifolia L. The reason for the accumulation of $\mathrm{Cd}$, Co and $\mathrm{Mn}$ in T. latifolia L. can be explained as a tolerance strategy due to its transfer index (TI) which is higher than 2.9. The enrichment coefficients of the metals present in the root compared to stem of $T$. latifolia L. were higher than 3.31 to 2.56 for Cd, 5.35 to 3.55 Co. But, for Mn were found to be lower 1.98 than 3.51 at $75 \%$. Similarly, the enrichment coefficients of all the metals, except for Co, in roots of $T$. latifolia L. were higher than 5.36. (TI) for Co (2.95) and $\mathrm{Mn}$ (2.55) which is absolutely better as compared to the enrichment coefficients of $\mathrm{Cd}$ (2.35) and TPH (3.45) in PSE. Thus, there is a possibility that PSE could be a source of important nutrients.

\section{Novelty}

The phytoremediation using $T$. latifolia $L$ in petroleum secondary effluent (PSE) having heavy metals (HMs) and total petroleum hydrocarbon (TPH) contaminated water-soil produced tremendous amounts of biomass, which is directly proportional to uptake of TPH and HMs. The optimal PSE dosage was 75\% for transfer index (TI), enrichment coefficients roots (ECR) and stability as well as removals of $17.98 \mathrm{TPH}$, 6.37 Co, $11.99 \mathrm{Mn}$ and $3.1 \mathrm{Cd} \mathrm{mg/g} \mathrm{DW}$ and at $100 \%$ of PSE showed the highest and lowest removal efficiencies for TPH and HMs lowest biomass growth. The maximum TI values for $\mathrm{HMs}$ and TPH between 1.15 to 3.45 from $25-75 \%$. The ECR in the roots of T. latifolia L. The higher for $5.10>4.05 \mathrm{TPH}$, $3.31>2.56 \mathrm{Cd}, 5.36>3.55 \mathrm{Co}$ than that in the enrichment coefficients at $75 \%$ of dosing PSE compared to $100 \%$ found lower due to toxicity. The significant decrease the contents of metals $\mathrm{Ca} 11.35, \mathrm{P} 1.71, \mathrm{Fe}$ $5.76, \mathrm{Mg} 2.45$ and protein 6.92, carbohydrate 5.65 in water was observed at $75 \%$ dosing of PSE. The per g mass growth using metals and micronutrient range increased from $<\mathrm{P}$ to $\mathrm{Fe}>\mathrm{Ca}>\mathrm{Mg}$ and Carbohydrate>Protein.

\section{Introduction}

Industrial wastewater contains various metals, hydrocarbons and inorganic compounds which are a threat to soil and water systems. With the onset of the industrial revolution, metal and nutrient pollution has intensified swiftly which has posed a major environmental and health risk to the ecosystem (Ahmad, $2018 ; 2019)$. As industrial pollution may cause major environmental and human health problems, we need to turn our attention to the effective and affordable tools required for the remediation of pollution from soil and water (Akpor et al. 2014; Kaumari and Tripathi, 2015). Heavy metals (HMs) and total petroleum hydrocarbons (TPHs) present in soil and water coming from the industrial processes, enters the food chain and ultimately the biosphere (Foshtomi et al. 2019; Al-Thani and Yaseen, 2020). Furthermore, the heavy metals leach into the soil surrounding them which also includes the agricultural 
fields and passed to food chain (Arivoli et al. 2015). Considering the Hazardous consequences of toxicity due to metal contamination, feverish efforts have been made to phytoremediate metals from the biosphere, soil and water system (Ahmad et al. 2010; Brankovic et al. 2015).

Typha latifolia L. and certain species like parthenium, rye grass, brassica have been identified to have potential to sequester of heavy metals in maximum amounts and feasibility of phytosequesteration of heavy metals from soil (Ahmad et al. 2019; Ahmad and Ahmad, 2014; Hammami et al. 2018). Typha latifolia L. plant have shown characteristics to faster growth of biomass with the sources available metals like $\mathrm{Fe}, \mathrm{Ca}, \mathrm{P}$ and nutrients from effluents, an under unfavorable condition to propagate growth rates compared to other hyperaccumulator plant for heavy metals (Banerjee et al. 2019; Afzal et al., 2019). Due to this characteristics, ecologically sustains and recommended as a suitable for phytoremediation of heavy metals and total hydrocarbon such as $\mathrm{Co}, \mathrm{Mn}, \mathrm{Ni}$, and $\mathrm{Cd}$ and had high biomass (Chayapan et al. 2015). The ecological engineered way for bioaccumulation, enrichment factor and transfer of HMs and TPH by plant biomass from contaminated sediments (Ali and Chaudhury, 2016). The micronutrients to change the physiological and molecular mechanisms responsible for metal hyperaccumulation and tolerance immunity in plant have been studied widely (Adeyeye, 2005; Truu et al. 2015).

Mechanism of pollution accumulation, it must be strongly emphasized that phytoremediations efficiency not only depends on plant factors such as metal tolerance, metal transfer, enrichment coefficient, biotransformation, metal accumulation, and so on (Yadav et al. 2018). It also depends on soil factors such as metal mobility and crucially, soil metals with wastes amendment and phytoavailability (Klomjek, 2016; Muthusaravanan et al. 2018; Zhaoet al. 2020). After all, rather than total concentrations, a major factor governing the phytotoxicity of metals in soil is their bioavailability (Pandey, 2017; Li et al. 2018; Prabakaran et al. 2019; Ahmad et al. 2020). Several aquatic and terrestrial plants is identified as a species able to phytoextraction of metals, nutrients and petroleum haydrocarbon from a multiply contaminated soil (Mustapha and Lense, 2018), take up and accumulate into its above-ground parts stem for the metals such as $\mathrm{Cd}, \mathrm{Co}, \mathrm{Cu}, \mathrm{Ni}, \mathrm{Mn}, \mathrm{Pb}$ and TPH (Galal et al. 2017). In eearlier studies it has been reported that $T$. latifolia $L$ has good tolerance and potential to withstand with higher levels of heavy metals and petroleum hydrocarbon (Samuel et al. 2015; Bokhari et al. 2019; Rehman et al., 2018; Steliga and Kluk, 2020).

The aim of this study to investigation the effect of petroleum secondary effluent concentrations on $T$. latifolia $L$ biomass and the phytoremediation of metals. Four dosage concentrations of $\operatorname{PSE}(25,50,75$ and $100 \%$ ) were tested in the vertical wetland. Analyses of T. latifolia L bionss growth, metals accumulation, transfer index, enrichment coefficients and nutrients role. Biomass growth and distribution of nutrients of chemical precipitates were monitored during the experimental periods

\section{Materials And Methods}

\section{Physico-chemical parameters}


Petroleum secondary effluent (PSE) was collected from Sur refinery, Oman. The petroleum is totally under the operation using extraction and refine petrol from the crude oil production. The levels of various physicochemical and heavy metals (Co, Mn and Cd) and TPH determined in PSE are shown in Table 1 and 2. The lake water collected from Sur lake and analyzed the properties of $\mathrm{pH} 7.9$, total dissolved solids $145 \mathrm{mgL}^{-1}$, total hardness $240 \mathrm{mgL}^{-1}$, calcium hardness $106 \mathrm{mgL}^{-1}$, dissolved oxygen $3.6 \mathrm{mgL}^{-1}$, chloride ion $83 \mathrm{mgL}^{-1}$, alkalinity $110 \mathrm{mgL}^{-1}, \mathrm{Na} 25, \mathrm{~K} 6 \mathrm{mgL}^{-1}$. The soil collected from university garden and had the properties of $\mathrm{pH} 7.4$, electrical conductivity-1.13 dsm 1 , total nitrogen (\%) 0.09 , total phosphorus (\%) 0.78, organic carbon (\%) 0.49 and Zn 23, Fe 5100, Mg 150, Ni $130 \mu \mathrm{g} / \mathrm{g}$ dry weight (DW), Pb and Hg non detectable.

\section{Experimental design and performance}

Typha latifolia L. were collected from Sur petroleum refinery, Oman. The plants were grown and the plant was raised in $75 " / 50 "$ plastic rectangular tubs wetlands. After raised the plants, in four tubs having 25 plants were irrigated on per day with different concentrations of petroleum secondary effluent (PSE). For the treatment application, the different concentrations ratio was applied as $25 \%$ petroleum secondary effluent (PSE) (25\% PSE + 75\% lake water), 50\% PSE (50\% PSE + 50\% lake water), 75\% PSE (75\% PSE + $25 \%$ lake water) and $100 \%$ PSE (100\% PSE) serial order of required dilution, of the petroleum secondary effluent. Three samples were taken for each treatment. Plant grown in lake water served as control. The $T$. latifolia L. from each set of tub working volume is $25 \mathrm{I}$ was placed under natural conditions as in open environment. The roots and stem from each plant were detached and washed repeatedly using tap water to remove unwanted debris and blotted. Fresh biomass contents were also recorded. For heavy metals (HMs) and TPH analysis in water and in plant parts, dried $1.0 \mathrm{~g}$ plant samples were ground in a grinder and digested in $\mathrm{HNO}_{3}: \mathrm{HClO}_{4}(3: 1, \mathrm{v} / \mathrm{v})$ at $80{ }^{\circ} \mathrm{C}$. Metals (Co, Mn and $\mathrm{Cd}$ ) were estimated by metals concentrations in the plant samples which were determined using Perkin Elmer Corporation Atomic Absorption Spectrophotometry (Perkin Elmer, AAS 1500) was used for calibration and quality assurance for each analytical batch. The detection limits of $\mathrm{Co}, \mathrm{Mn}$ and $\mathrm{Cd}$ were $0.5,1.0$ and $0.01 \mu \mathrm{g} / \mathrm{l}$, respectively. Replicate $(n=3)$ analyses were conducted to assess the precision of the analytical techniques. Triplicate analysis for each metals varied by no more than $5 \%$. I conducted the estimation biomass growth after 60 days of experimental periods plants were collected. The study of root, stem length, fresh and dry weight of root and stems. For the estimation of dry biomass kept at $85^{\circ} \mathrm{C}$ for three days for weighted biomass.

\section{Analysis of samples}

\section{Analysis of protein and carbohydrate}

Plant samples for the estimation of carbohydrate (Murphy, 1958) and protein according to Ahmad et al (2019) $1 \mathrm{~g}$ of fresh plant tissues was crushed in $3 \mathrm{ml}$ of potassium phosphate buffer $(50 \mathrm{mM}, \mathrm{pH}=7.0)$ and centrifuged for $20 \mathrm{~min}$. Supernatant $(0.1 \mathrm{ml})$ was added to test tube and diluted with $1 \mathrm{ml}$ of distilled water. From $5 \mathrm{ml}$ of reagent $C$ (Reagent $A$ comprised of sodium carbonate (2\%) in sodium hydroxide $(0.1$ $\mathrm{N})$, Reagent B comprised of copper sulphate $(0.5 \%)$ in potassium sodium tartarate (1\%). Reagent C 
consists of $100 \mathrm{ml}$ of reagent $A$ and $2 \mathrm{ml}$ of reagent $B$ ) was poured into the test tube and incubated at room temperature for $10 \mathrm{~min}$. After this $0.5 \mathrm{ml}$ of Folin-Ciocalteu reagent was added to the reaction mixture in the test tube followed by an incubation of $30 \mathrm{~min}$ at $30^{\circ} \mathrm{C}$ at dark condition. To determine the protein and carbohydrate content, BSA (bovine serum albumin) standard curve was used, absorbance was analyses at $660 \mathrm{~nm}$ The concentration of protein and carbohydrate was expressed as $\mathrm{mg} / \mathrm{g}$ fresh weight.

\section{Bioaccumulation of HMs and TPH}

The bioaccumulation, translocation and phytoextraction of metals and TPH by the T. latifolia L. was assessed at the level in roots and stem. The method of total metals and TPH analysis in different plant parts were prepared as an according to methods APHA (1998) using atomic absorption spectrophotometry (Perkin Elmer, AAS 1500). Plant mass was being analyzed for transfer index (TI) including stem concent. Stem biomass include root concent. Root biomass divided by stem and root biomass multiplies days of growth

\section{Enrichment coefficient factor (ECF)}

The plant was analysed the enrichment coefficient factor (ECF) for stem and roots from soil values greater than or equal to 1.5 ( $E f \geq 1$ ) expresses that it is a hyperaccumulator and decent for phytoremediation practice. It also indicates that the plant has a high ability to accumulate and tolerate a higher concentration of heavy metals and TPH in its petroleum secondary effluent. The enrichment factor (Ef) for various heavy metals accumulated in the tissue of $T$. latifolia L. after phytoremediation was calculated using Eq. 1.

Enrichment coefficient $(E C)=[C(1) f] /[C i]$ Eq. 1

where $\mathrm{Cf}$ and $\mathrm{Ci}$ are the mean metal and TPH concentration in the effluent sample and concentration of value in the tissue of the plant, respectively. The plants materials and water were collected and statistically analyzed. The treatments were carried out in triplicates and the data furnished in figures and tables are mean \pm SE (Standarderror of the mean of three replicates).

Statistical analyses of samples for two-way analysis of variance (ANOVA) was done on all the data to confirm the variability of data and validity of results. Differences among means were determined by the analyses of variance. The SPSS (Statistic Program for Social Sciences) statistical program package (Release 12.0) was used for statistical analyses of data. Different letters (a- strongly significant and blower significant) mean significant differences between treatment and control at a part of plant, error bars indicate the standard error of individual measurements.

\section{Results And Discussion}


The physico-chemical, metals, heavy metals (HMs), and total petroleum hydrocarbon (TPH) properties of petroleum secondary effluent (PSE) are shown in Table 1 and 2. From the Fig. 1, was found to be PSE doses exposures. Bio-accumulation of HMs and TPH in parts of the plant at $75 \%$ was highest compared to $100 \%$ doses of PSE represented in Fig. 1. The bioaccumulation of TPH compared with metal was found higher and showed that the T. latifolia L Co>Mn>Cd, (Fig. 2), has the maximum $49 \mathrm{~cm}$ root and $105 \mathrm{~cm}$ shoot, the plant exhibited better growth at $75 \%$ of PSE. It's may be due to availability of macro nutrients and calcium, magnesium and iron in cellular level with the improvement of structure of chloroplast showed growth of biomass at lower concentration of $\mathrm{Cd}$ and $\mathrm{Co}$. As a result, the roots were unable to deliver the nutrients to shoot, for which the growth of the plants were affected (Fig. 2). Similar results were observed by others researchers (Peris et al. 2017; Ali et al. 2020). The inhibition of the root growth is a primary symptoms of heavy metal toxicity which can be taken as a measure for root stress tolerance (Ali at al. 2018; Ahmad et al. 2020).

\section{Impact of dosing petroleum secondary effluent}

The applied concentration of PSE $25-50 \%$ did not show any significant accumulation of HMs and TPH in plant parts. However, HMs and TPH accumulations rate of stem> root also depends on the doses of PSE. The highest amount of TPH was transferred in stem 894 and root $477 \mu \mathrm{g} / \mathrm{g}$ DW was found at $75 \%$ doses of PSE. However, a much lower accumulation of TPH was observed at $25-50 \%$ or higher concentrations i.e. $100 \%$ of PSE. The accumulation of HMs in plant from PSE were Mn, Co and Cd, $(638,653,186 \mu \mathrm{g} / \mathrm{g})$ in root, $(458,768,198 \mu \mathrm{g} / \mathrm{g})$ in stem and $(368,463,86 \mu \mathrm{g} / \mathrm{g})$ in leaves T. latifolia L and final remained (precipitate) heavy metal concentration in the water are presented in (Fig. 2) respectively. The lowest accumulation of metal $\mathrm{Mn}$ and $\mathrm{Cd}$, due to the initial concentration of metals in PSE was lowest compared to TPH and Co. However, the mass of the plants average accumulation for TPH and HMs from PSE to root to stem indicated by the depend on biomass enrichment coefficient and transfer index of metals (Ali et al. 2019; Anudeep et al. 2020).

\section{Variation of HMs and TPH in plants}

The accumulation of the HMs and TPH reduction was $\mathrm{TPH}>\mathrm{Co}>\mathrm{Mn}>\mathrm{Cd}$ from petroleum secondary effluent (PSE) (Fig. 2). The levels of TPH and HMs accumulated in root and stem were significantly different in different parts of plant at different of PSE concentrations. However, the TPH and HMs concentrations in lake water to soil lower than the parts of the plant (Fig. 2). The TPH and HMs bioaccumulation reached up to $97.3 \%$ for $\mathrm{TPH}, 97.5 \%$ for $\mathrm{Co}, 91 \%$ for $\mathrm{Mn}$, and $42.7 \%$ for Cd (Fig. 2). The accumulation of TPH and HMs was observed in this experiment found higher compared to other studies (Ahmad et al. 2019; Jaskulaki et al. 2020). In our study, TPH and HMs accumulation in the root and stem of $T$. latifolia $L$ increased along with biomass with the increasing dosing of PSE. Similar observations by other researcher were also found (Galal and Shehata, 2015; Ahmad et al. 2019).

\section{Impact on growth and yields of biomass}


The high concentration of TPH and HMs in T. latifolia L tissue could decrease the growth, biomass (Waheed et al. 2019; Ahmad et al. 2020). The reduction in biomass of plants at $100 \%$ might be due to toxicity of TPH and HMs, which corroborates our previous results using varying concentrations of HMs on growth of rye grass plants (Ahmad et al. 2019). The growth and development of roots were affected at very high concentration of PSE available on T. latifolia L. As a result, the roots were unable to deliver the nutrients to shoot, for which the growth of the biomass plants were affected (Rehman et al., 2019). Similar findings were estimated by related researchers (Ahmad and Ahmad, 2014; Jampsari and SaengNigam, 2019: Ahmad et al. 2019). The inhibition of the biomass is a primary symptom of TPH and HMs toxicity which can be taken as a measure for plant stress tolerance (Ahmad et al. 2010; Newete and Byrne, 2016). The result showed that the biomass of plant was able to phytoremediate the metals petroleum secondary effluent (Ahmad et al. 2019; Ali et 2019). The results of this experiment showed that T. latifolia $\mathrm{L}$ plant have the biomass of dry weight was $45 \mathrm{~g}$ at $25 \%, 78 \mathrm{~g}$ at $50 \%, 97 \mathrm{~g}$ at $75 \%$ and $23.9 \mathrm{~g}$ at $100 \%$, so that at $75 \%$ dosing PSE showed highest biomass compared with lower and $100 \%$ PSE (Fig. 3). The plants biomass was observed in Fig. 3, biomass growth totally depends on PSE concentration at $75 \%$, biomass $97 \mathrm{~g} / \mathrm{Kg}$ highest than lower and higher concentration of PSE compared with control. Thus, the biomass development of the plant was significant at 25 and $75 \%$ dosing as compared to the biomass of at $100 \%$ PSE, as a result biomass growth increased constantly on all the amendments except at $100 \%$ PSE dosing (Fig. 3).

\section{Transfer index for TPH and HMs}

Transfer index factor can be used to estimate a plant's potential for phytoremediation purpose in $T$. latifolia are shown in Table 3. The bioaccumulation of TPH and HMs rate depend on PSE doses and biomass. The transfer index (TI) increases with increase in the concentration of TPH and HMs but the bio-concentration in plant decreases with the application of higher concentration of TPH and HMs (Table 3). The maximum value of $\mathrm{Tl}$, was observed 1.9 at $75 \%$ dosing. Bioaccumulation of TPH and HMs in biomass to transfer via transportation index $(\mathrm{TI})$ can be considered as an effective tool for identification of hyper accumulator species. The uptake of metals from soil to plants and then translocation those to aerial parts allow to determine the capabilities of individual species to accumulate the metals and therefore to recognized as a potential hyper accumulator (Rana and Maiti, 2018; Ahmad et al. 2020). The Tls changed between 0.65 to 2.95 for HMs and for TPH between 1.15 to 3.45 from 25-75\% dosing of PSE, whereas at decrease at $100 \%$ compared to control (Table 3). The mean TI for Cd, Co and Mn in T. latifolia L. was higher than 2.56 at $75 \%$ dosing of PSE, but mean $\mathrm{TI}$ for higher dosing metals were generally lower due to toxicity and did not effectively transfer heavy metals from root to plant body (Table 3 ). The TPH for $\mathrm{Tl}$ at $75 \%$ dosing was 3.45 compared to higher dosing lower transfer due to availability with plants parts (Foshtomi et al. 2019; Ahmad et al. 2020). The plant parts having ability was in the order of $\mathrm{TPH}>\mathrm{Co}>\mathrm{Cd}>\mathrm{Mn}$. The values of $\mathrm{Tl}$ in different dosing of PSE indicated that different metal has different phytotoxic effect on T. latifolia (Table 3). Ahmad et al. (2010) and Ahmad and Ahmad (2014) observed that $\mathrm{TI}$ higher than 2.0 were determined in metal hyper accumulator plants whereas $\mathrm{TI}$ was lower than 1.5 in metal accumulator plants. In this study TI higher than 2.0 indicates an efficient ability to transport 
metal from soil to root to stem, most highly effective remediate metals due to efficient metal transporter systems through its biomass (Ariolo et al. 2015; Klomjek, 2016).

\section{Enrichment coefficient for the root and stem}

The plant showed bio-concentration of TPH and HMs indicates the efficiency of the plants to eliminate the TPH and HMs metals from the soil to plant. The enrichment coefficients roots (ECR) in the roots of $T$. latifolia L. were higher for $5.10>4.05 \mathrm{TPH}, 3.31>2.56 \mathrm{Cd}, 5.36>3.55 \mathrm{Co}$ at $75 \%$ of dosing PSE compared to $100 \%$ found lower due to bioavailability toxicity (Table 3 ). This characteristics of plant means that the roots of $T$. latifolia L. showed highest capacity for $\mathrm{TPH}>\mathrm{CO}>\mathrm{Cd} \otimes \mathrm{Mn}$.. However, the bioaccumulation of TPH and HMs by the root of T. latifolia L. was higher due to ECR more than 3.0 except for Mn (Table 3). Enrichment coefficients are a very important factor, which indicate phytoremediation of a given species (Ahmad et al. 2011; Kumari and Tripathi, 2015; Hammami et al. 2018; Ali et al. 2018). (Table 3). The TPH and HMs concentrations in root>shoot were generally higher than that in soil (Table 3). Researcher supported our findings to this situation indicated a special ability of $T$. latifolia $L$ to with stand bioaccumulate, transfer of TPH and HMs from PSE soil and well grown of biomass their root and stem (Li et al 2018; Outa et al. 2020; Steliga and Daluk, 2020).

\section{Tolerance strategy of plants and chemical precipitates in biomass-metals, HMs and TPH}

Fig. 4 and 5 shows the protein and carbohydrate content in T. latifolia $L$ at $75 \%$ dose of petroleum secondary effluent (PSE) stabilized at around 87.5 and $73.216 .4 \mathrm{mg} / \mathrm{Kg} \mathrm{DW}$. The content of Fe, P, Mg and $\mathrm{Ca}$ in the plant at $75 \%$ dosage is $98.5,0.7,2.5$ and $23.6 \mathrm{mg} / \mathrm{Kg}$ respectively. After cultivating for 45 days, it is evident that the metal content in the plant decreased to $90 \%$ (At 100\% concentration of PSE) (Fig. 4). However, the contents of $\mathrm{Fe}, \mathrm{Mg}, \mathrm{Ca}$ and other important metals for plant growth, at $50-75 \%$ of PSE remained higher than those at $25,100 \%$, indicating that iron and calcium precipitate and the stem chloroplast adheres to the plant (Fig. 4). The results of this analysis supports the conclusion that stem of T. latifolia L containing metal elements; $\mathrm{Ca}$ and $\mathrm{Fe}$ and macronutrients like protein, carbohydrate can be observed at $50-75 \%$ dose but not at $25,100 \%$ of PSE dose (Fig. 4). Due to the concentration of Fe and $\mathrm{Ca}$ at the dosing of 50 and $75 \%$, they form hematite (Fe2O3) and calcium pyrophosphate (Ca2P2O7). Along with (Fe2O3) and (Ca2P2O7), (Ca2Fe2O5) and ( $\mathrm{Fe} 3(\mathrm{PO} 4) 2(\mathrm{OH}) 3)$ were also found in the plant at 75\%., (Rout and Sahoo, Gao and Cutright, 2019). After 60 days of cultivation of T. latifolia L, the contents of $P$, Fe and $\mathrm{Ca}$ in the plant at $100 \%$ was lower than that at $75 \%$ dose of PSE (Fig. 4). Taking into consideration, the contents of macro and micronutrients increased rapidly at 50 to $75 \%$ but not at 25 , $100 \%$, this implies that the growth of biomass of $T$. latifolia $L$ increases at 50 to $75 \%$ dosing of PSE (Fig. 4) (Mustapha and Lens, 2018; Bokhari et al. 2019).

The amount of TPH, HMs and metals nutrients transferred from the soil to the plant biomass and the remaining masses of chemical precipitations are depicted in Fig. 5 and Table 4. Therefore, it can be understood that the weight ratio of TPH and HMs precipitations in soil is $11.6 \mu \mathrm{g} / \mathrm{g}$ with the biomass growth of plant $109 \mathrm{~g} / \mathrm{Kg}$ in $75 \%$ compared with the biomass $37.5 \mathrm{~g} / \mathrm{Kg}$ and $56.7 \mu \mathrm{g} / \mathrm{g}$ at $100 \%$ dosing of PSE (Fig. 5). As shown in Fig. 5, the contents of HMs and TPH in soil of range $(11.6 \mu \mathrm{g} / \mathrm{g})$ were relatively 
stable in $75 \%$, while the contents of TPH, HMs in soil were shown to increase as the dosing of PSE range increased from 25 and $100 \%$. These results prove that $75 \%$ of PSE per gm of biomass of T. latifolia $\mathrm{L}$ removed 17.98 TPH, 6.37 Co, $11.99 \mathrm{Mn}$ and $3.1 \mathrm{Cd} \mathrm{mg/g} \mathrm{DW}$ respectively. The amounts of Co and Mn removed from soil were observed highest than that utilized by the plant in both control and treatment (Galal et al. 2017: Ahmad et al. 2019; Ali et al. 2020)).

\section{Role of metals and micronutrient for HMs and TPH toxicity removal}

In Table 4, experiment was performed on the system in order to determine the TPH and HMs' removal pathways. The dosing of PSE 75\%, the remained contents in water of protein-carbohydrate and $\mathrm{Ca}, \mathrm{Fe}$, $\mathrm{Mg}$ and $\mathrm{P}$ in water decreased significantly due to mass balance to maximum amount of metals and microonutrient transfer in T. latifolia L. for biomass growth. The significant decrease the contents of $\mathrm{Ca}$ 11.35, P 1.71, Fe 5.76, Mg 2.45 and protein 6.92 , carbohydrate 5.65 in water was observed at $75 \%$ dosing of PSE. The per g mass growth using metals and micronutrient range increased from $<\mathrm{P}$ to $\mathrm{Fe}>\mathrm{Ca}>\mathrm{Mg}$ and Carbohydrate>Protein. These results clearly confirm that growth plant biomass utilized more $97.35 \%$ of TPH and HMs, had low content of chemical precipitations (Ahmad et al. 2011; Adeyeye, 2005; Ahmad and Ahmad, 2014; Jampsari and Saeng-Ngam, 2019) or release in water (Table 4). The plants used for the phytoremediation of with stand long exposure of these TPH and HMs might bring about accumulation and increase the content inside the plants. However, the fact that TPH and HMs accumulated in plants from PSE, despite the presence of TPH and HMs in water- soil, their concentrations were relatively very low and fulfilled the conditions for the discharge of treated effluent (Rana and Maiti, 2018; Truu et al. 2015; Gao and Cutright, 2019; Ahmad et al. 2019; Ahmad et al. 2020; Hejna et al. 2020).

\section{Conclusions}

The experiment for phytoremediation T. latifolia L in PSE having TPH and HMs contaminated water- soil produced tremendous amounts of biomass, which is directly proportional to uptake of TPH and HMs. The optimal PSE dosage was 75\% for TI, ECR and ECR formation and stability as well as removals of removed 17.98 TPH, 6.37 Co, $11.99 \mathrm{Mn}$ and $3.1 \mathrm{Cd} \mathrm{mg/g} \mathrm{DW}$ and at 100\% of PSE showed the highest and lowest removal efficiencies for TPH and HMs lowest biomass growth. The maximum TI values for HMs and TPH between 1.15 to 3.45 from 25-75\%. The ECR in the roots of T. latifolia L. were higher for $5.10>4.05 \mathrm{TPH}, 3.31>2.56 \mathrm{Cd}, 5.36>3.55 \mathrm{Co}$ at $75 \%$ of dosing PSE compared to $100 \%$ found lower due to toxicity. The significant decrease the contents of metals Ca 11.35, P 1.71, Fe 5.76, Mg 2.45 and protein 6.92, carbohydrate 5.65 in water was observed at $75 \%$ dosing of PSE, when the per g mass growth using metals increased from $<\mathrm{P}$ to $\mathrm{Fe}>\mathrm{Ca}>\mathrm{Mg}$ and micronutrient range carbohydrate $>$ protein. However, growth of biomass not only increased the biomass, TPH and HMs enrichment coefficient ratio, but alleviated the inhibition to PSE. The remained pollution in soil and water only $9.1 \%$ though considered as an effective tool for hyper accumulator and ecologically sustainable species.

\section{Declarations}


Ethical Approval Approvedauthor

Consent to Participate Author are consent to participate in this study

Consent to Publish Author given concern to publish this work

Authors Contributions Author well contributed in this research

Funding No funding sources available

Competing Interests The authors declare that they have no conflicts of interest.

Availability of data and materials Self-laboratory work and original data generated in the course of the research

\section{Acknowledgements}

The authors wish to thanks R\&D panels of UoN for valuable discussions on application of granular material for development granules for industrial wastewater treatment and as a source of energy and fully supported by Professor Anwar Ahmed Research Cluster Group Energy and environment sustainable technology.

\section{References}

1. Afzal M, Arslan M, Müller JA et al (2019) Floating treatment wetlands as a suitable option for largescale wastewater treatment. Nat Sustain 2:863-871

2. Ahmad A, Wahid ZA, Ghufran R (2010) Metals Cd, As, Cu, and Zn transfer through dry to rehydrated biomass of Spirulina Platensis from wastewater. Polish J of Environmental Studies 19(5):674-682

3. Ahmad A, Ghufran R, Zularisam AW (2011) Phytosequestration of metals in selected plants growing on a contaminated Okhla industrial areas, Okhla, New Delhi, India. Wat Air Soil Pollut 217:255-266

4. Adeyeye El (2005) Distribution of major elements ( $\mathrm{Na}, \mathrm{K}, \mathrm{Ca}, \mathrm{Mg})$ in the various anatomical parts of Fadama crops in Ekiti State, Nigeria. Bullet of the Chem Socie of Ethiopia 19(2):175-183

5. Ahmad A, Ghufran R, Al-Hosini T (2020) Bioavailability of zinc oxide nano particle with fly ash soil for the remediation of metals by Parthenium hysterophorus. J of Environ Heal Scie Engin. DOI:10.1007/s40201-019-00434-2

6. Ahmad A, Reddy SS, Ghufran R (2019) Model for bioavailability and metal reduction from soil amended with petroleum wastewater by rye-grass $\mathrm{L}$. International $\mathrm{J}$ of Phytoremediation. DOI:10.1080/15226514.2018.1537243

7. Ahmad A, Ahmad OI (2014) Remediation rates of soil contaminated with heavy metals reduction through translocation from Parthenium hysterophorus. Chem Ecol.

DOI:10.1080/02757540.2013.871269 
8. American Public Health Association (APHA) (1998) Standard methods, 19th edn. American Public Health Water Works Association and Water Pollution Control Federation, Washington, DC

9. Ali S, Abbas Z, Rizwan M, Zaheer IE, Yavaş I, Ünay A, Abdel-Daim MM, Bin-Jumah M, Hasanuzzaman M, Kalderis D (2020) Application of Floating Aquatic Plants in Phytoremediation of Heavy Metals Polluted Water: A Review. Sustainability 12, 1927

10. Al-Thani RF, Yasseen BT (2020) Phytoremediation of polluted soils and waters by native Qatari plants: Future perspectives. Environ Pollut 259:113-694

11. Ali SY, Chaudhury S (2016) EDTA-Enhanced Phytoextraction by Tagetes sp. and Effect on Bioconcentration and Translocation of Heavy Metals. Environ Process 3:735-746

12. Akpor OB, Ohiobor GO, Olaolu TD (2014) Heavy metal pollutants in wastewater effluents: sources, effects and remediation. Adv Biosci Bioengin 2:37-43

13. Ali T, Jahantab E, Jafari M, Motesharezadeh M, Zargham N, Aman MS (2019) Assessment of TPH and nickel contents associated with tolerant native plants in petroleum-polluted area of Gachsaran, Iran. Arabian J.I of Geoscie. 12(10)

14. Ali Z, Mohammad A, Riaz Y, Mas., Quraishi UM, Malik RN (2018) Treatment efficiency of a hybrid constructed wetland system for municipal wastewater and its suitability for crop irrigation. Int $\mathrm{J}$ of Phytoreme 20(11):1152-1161

15. Anudeep N, Yadav DK, Christian RA (2020) A small-scale study of plant orientation in treatment performance of vertical flow constructed wetland in continuous flow. Int $J$ of Phytore $0(0): 1-8$

16. Arivoli A, Mohanraj R, Seenivasan R (2015) Application of vertical flow constructed wetland in treatment of heavy metals from pulp and paper industry wastewater. Environ Scie Pollut Resear 22(17):13336-13343

17. Banerjee R, Goswami P, Lavania S, Mukherjee A (2019) Vetiver grass is a potential candidate for phytoremediation of iron ore mine spoil dumps. Ecol Engi 132:120-136

18. Bokhari SH, Mahmood-Ul-Hassan M, Ahmad M (2019) Phytoextraction of Ni, Pb and, Cd by duckweeds. Int J of Phytore 21(8):799-806

19. Brankovic S, Glišić R, Topuzovic M, Marin M (2015) Uptake of seven metals by two macrophytes species: potential for phytoaccumulation and phytoremediation. Chem Ecol 31:583-593

20. Chayapan P, Kruatrachue M, Meetam M, Pokethitiyook P (2015) Phytoremediation potential of Cd and $\mathrm{Zn}$ by wetland plants, Colocasia esculenta L. Schott., Cyperus malaccensis Lam., and Typha angustifolia L. grown in hydroponics. J of Environ Biolo 36(5):1179-1183

21. Foshtomi MY, Oryan S, Taheri M, Bastami KD, Zahed MA (2019) Composition and abundance of microplastics in surface sediments and their interaction with sedimentary heavy metals, PAHs and TPH (total petroleum hydrocarbons). 2019. Marine Pollut. Bulletin 149: 10-16

22. Galal TM, Shehata SH (2015) Bioaccumulation and translocation of heavy metals by Plantago major L. grown in contaminated soils under the effect of traffic pollution. Ecol Indic 48:244-251 
23. Galal TM, Gharib FA, Ghazi SM, Mansour KH (2017) Phytostabilization of heavy metals by the emergent macrophyte Vossia cuspidata (Roxb.) Griff.: a phytoremediation approach. Int $\mathrm{J}$ of Phytore 19:992-999

24. Guo L, Cutright TJ (2019) Comparison of Metal Plaque Formation and Metal Accumulation in Reeds Cultured in Acid Mine Drainage Solutions and Soils. Soil Sediment Contamination: Int J 28(7):670683

25. Hammami H, Alaie E, Dastgheib SMM (2018) The ability of Silybum marianum to phytoremediate cadmium and/or diesel oil from the soil. Int $\mathrm{J}$ of Phytor 20(8):756-763

26. Jaskulak M, Grobelak A, Vandenbulcke F (2020) Modelling assisted phytoremediation of soils contaminated with heavy metals-Main opportunities, limitations, decision making and future prospects. chemosphere. 126-196

27. Klomjek P (2016) Swine wastewater treatment using vertical subsurface flow constructed wetland planted with Napier grass. Sustainable Environ Resear 26(5):217-223

28. Kumari M, Tripathi BD (2015b) Efficiency of Phragmites australis and Typha latifolia for heavy metal removal from wastewater. Ecotox Environ Safe 112:80-86

29. Jampsari K, Saeng-Ngam S (2019) Phytoremediation and Accumulation of Cadmium from Contaminated Saline Soils by Vetiver Grass. Environ Control in Biol 57(3):61-67

30. Li X, Shen H, Zhao Y, Cao W, Hu C, Sun C (2019) Distribution and Potential Ecological Risk of Heavy Metals in Water, Sediments, and Aquatic Macrophytes: A Case Study of the Junction of Four Rivers in Linyi City, China. Int J Environ Res Public Health 16:2861

31. Murphy RP (1958) A method for the extraction of plant samples and the determination of total soluble carbohydrates. Journal of the Science of Food Agriculture 9:714-717

32. Muthusaravanan S, Sivarajasekar N, Vivek JS (2018) Phytoremediation of heavy metals: mechanisms, methods and enhancements. Environ Chem Lett 16:1339-1359

33. Mustapha HI, Lens PNL (2018) Constructed Wetlands to Treat Petroleum Wastewater. In: Prasad R, Aranda E (eds) Approaches in Bioremediation. Nanotechnology in the Life Sciences. Springer, Cham. DOlhttps://doi.org/10.1007/978-3-030-02369-0_10

34. Muthusaravanan S, Sivarajasekar N, Vivek JS, Vasudha Priyadharshini S, Paramasivan N, Dhakal T, Naushad M (2020) Research Updates on Heavy Metal Phytoremediation: Enhancements, Efficient Post-Harvesting Strategies and Economic Opportunities. Green Materials for Wastewater Treatment 38, Springer, DOI: 10.1007/978-3-030-17724-9_9

35. Newete SW, Byrne MJ (2016) The capacity of aquatic macrophytes for phytoremediation and their disposal with specific reference to water hyacinth. Environ Sci Pollut Res 23:10630-10643

36. Outa JO, Kowenje CO, PlessI C (2020) Distribution of arsenic, silver, cadmium, lead and other trace elements in water, sediment and macrophytes in the Kenyan part of Lake Victoria: spatial, temporal and bioindicative aspects. Environ Sci Pollut Res 27:1485-1498

37. Prabakaran K, Li J, Anandkumar A, Leng Z, Du D (2019) Managing environmental contamination through phytoremediation by invasive plants: A review. Ecological Engineer 138:28-37 
38. Peris PM, Gómez JC, Herbert JH, Fraile DB (2017) Ecological restoration of a former gravel pit contaminated by a massive petroleum sulfonate spill. A case study: Arganda del Rey. Madrid (Spain) Ecological Engineer 100:73-88

39. Pandey VC (2015) Assisted phytoremediation of fly ash dumps through naturally colonized plants Ecological Engineer. 82, 1-5

40. Rehman K, Imran A, Amin I, Afzal M (2019) Enhancement of oil field-produced wastewater remediation by bacterially-augmented floating treatment wetlands. Chemosphere 217:576-583. doi:10.1016/j.chemosphere.2018.11.041

41. Rout GR, Sahoo S (2015) Role of iron in plant growth and metabolism. Reviews in Agricult Scie 3:124

42. Rana V, Maiti SK (2018) Municipal wastewater treatment potential and metal accumulation strategies of Colocasia esculenta (L.) Schott and Typha latifolia L. in a constructed wetland. Environ Monit Assess 190:328

43. Samuel E, Agarry, Kigho M, Oghenejoboh, Ganiyu K, Latinwo, Chiedu N, Owabor (2018) Biotreatment of petroleum refinery wastewater in vertical surface-flow constructedwetland vegetated with Eichhornia crassipes: lab-scale experimental and kinetic modelling. Environ Technol. DOI:10.1080/09593330.2018.1549106

44. Hejna M, Moscatelli A, Stroppa N, Onelli E, Rossi L (2020) Bioaccumulation of heavy metals from wastewater through a Typha latifolia and Thelypteris palustris phytoremediation system. Chemosphere 241:125018

45. Steliga T, Kluk D (2020) Application of Festuca arundinacea in phytoremediation of soils contaminated with $\mathrm{Pb}, \mathrm{Ni}, \mathrm{Cd}$ and petroleum hydrocarbons 2020. Ecotox Environ Safety 194:110409

46. Truu J, Truu M, Espenberg M, Nõlvak H, Juhanson J (2015) Phytoremediation and plant-assisted bioremediation in soil and treatment wetlands: a review. The Open Biotechnol J 9:85-92

47. Waheed H, llyas N, Raja NI, Mahmood T, Ali Z (2019) Heavy metal phyto-accumulation in leafy vegetables irrigated with municipal wastewater and human health risk repercussions. Int $\mathrm{J}$ of Phytore 21(2):170-179

48. Yadav KK, Gupta N, Kumar A, Reece LM, Khan SA (2018) Mechanistic understanding and holistic approach of phytoremediation: A review on application and future prospects. Ecol Eng 120:274-298

49. Zhao M, Zeng S, Liu S, Li Z, Jing L (2020) Metal accumulation by plants growing in China: Capacity, synergy, and moderator effects Ecological Engineer. 1481, 105790

\section{Tables}

\section{Table 1.}

Physico-chemical properties of petroleum secondary effluent and values are means of three replicates \pm SD 


\begin{tabular}{lc}
\hline Parameters & Water sample \\
\hline $\mathrm{pH}$ & $5.79 \pm 0.16$ \\
$\mathrm{BOD}(\mathrm{mg} / \mathrm{l})$ & $1096 \pm 1.98$ \\
$\mathrm{COD}(\mathrm{mg} / \mathrm{l})$ & $1917 \pm 2.79$ \\
$\mathrm{Cl}^{-1}(\mathrm{mg} / \mathrm{l})$ & $1895 \pm 1.45$ \\
$\mathrm{TDS}$ & $1205 \pm 1.09$ \\
Alkalinity $(\mathrm{mg} / \mathrm{l})$ & $0.76 \pm 0.019$ \\
Sulfate $(\%)$ & $2.9 \pm 0.021$ \\
Calcium $(\mathrm{mg} / \mathrm{l})$ & $756.45 \pm 1.21$ \\
Magnesium $(\mathrm{mg} / \mathrm{l})$ & $385.2 \pm 1.10$ \\
\hline
\end{tabular}

\section{Table 2.}

Metals and TPH (total petroleum hydrocarbon) contents of petroleum secondary effluent-PSE values are means of three replicates \pm SD

\begin{tabular}{ll}
\hline Metal ions $(\mathrm{mg} / \mathrm{L})$ & PSE sample \\
\hline $\mathrm{Cd}$ & $3.804 \pm 1.8$ \\
$\mathrm{Co}$ & $7.899 \pm 2.6$ \\
$\mathrm{Mn}$ & $14.733 \pm 3.7$ \\
$\mathrm{TPH}$ & $19.771 \pm 5.11$ \\
\hline
\end{tabular}

\section{Table 3.}

Studies of enrichment coefficient and translocation index for petroleum secondary effluent having metals and TPH in planted Typha latifolia L. through experimental periods $(\mathrm{n}=3)$

\begin{tabular}{|c|c|c|c|c|c|c|c|c|c|c|c|c|}
\hline PSE & $\mathrm{Cd}$ & & & Co & & & Mn & & & TPH & & \\
\hline & ECS & ECR & $\mathrm{TI}$ & ECS & ECR & $\mathrm{TI}$ & ECS & ECR & $\mathrm{TI}$ & ECS & ECR & $\mathrm{TI}$ \\
\hline 0 & 0.21 & 0.15 & 0.22 & 0.15 & 0.45 & 0.19 & 0.10 & 0.11 & 0.13 & 0.35 & 0.25 & 0.20 \\
\hline 25 & 0.98 & 1.23 & 1.15 & 0.91 & 1.12 & 0.98 & 0.95 & 0.85 & 0.65 & 1.95 & 1.16 & 1.15 \\
\hline 50 & 1.23 & 1.85 & 1.95 & 1.85 & 2.56 & 1.75 & 1.85 & 1.05 & 1.15 & 3.45 & 2.98 & 2.35 \\
\hline 75 & 2.56 & 3.31 & 2.35 & 3.55 & 5.35 & 2.95 & 3.51 & 1.98 & 2.55 & 4.05 & 5.10 & 3.45 \\
\hline 100 & 1.09 & 1.14 & 1.11 & 1.19 & 1.35 & 1.15 & 1.43 & 1.15 & 1.15 & 3.95 & 3.10 & 1.90 \\
\hline
\end{tabular}


Table 4: Metals, micronutrient and TPH, HMs in petroleum secondary effluent (PSE) concentrations at $75 \%$ after treatment release in water.

\begin{tabular}{|c|c|c|c|}
\hline \multicolumn{2}{|c|}{ Metals and Micronutrient Element } & \multicolumn{2}{|c|}{ Heavy metals and TPH (mg/L) } \\
\hline & $\begin{array}{l}\text { PSE treated concentrations } \\
(\mathrm{mg} / \mathrm{L})\end{array}$ & & $\begin{array}{l}\text { PSE treated effluent concentrations } \\
(\mathrm{mg} / \mathrm{L})\end{array}$ \\
\hline $\mathrm{Ca}$ & $11.35 \pm 1.3^{\mathrm{a}}$ & $\mathrm{TPH}$ & $0.93 \pm 0.3^{a}$ \\
\hline $\mathrm{P}$ & $1.71 \pm 1.3^{b}$ & Co & $0.11 \pm 0.08$ a \\
\hline $\mathrm{Fe}$ & $5.76 \pm 1.7^{a}$ & $\mathrm{Mn}$ & $0.16 \pm 0.09^{b}$ \\
\hline $\mathrm{Mg}$ & $2.45 \pm 1.9^{a}$ & $\mathrm{Cd}$ & $0.015 \pm 0.005^{a}$ \\
\hline Protein & $6.92 \pm 3.2^{\mathrm{a}}$ & & \\
\hline Carbohydrate & $5.65 \pm 3.9^{a}$ & & \\
\hline
\end{tabular}

\section{Figures}




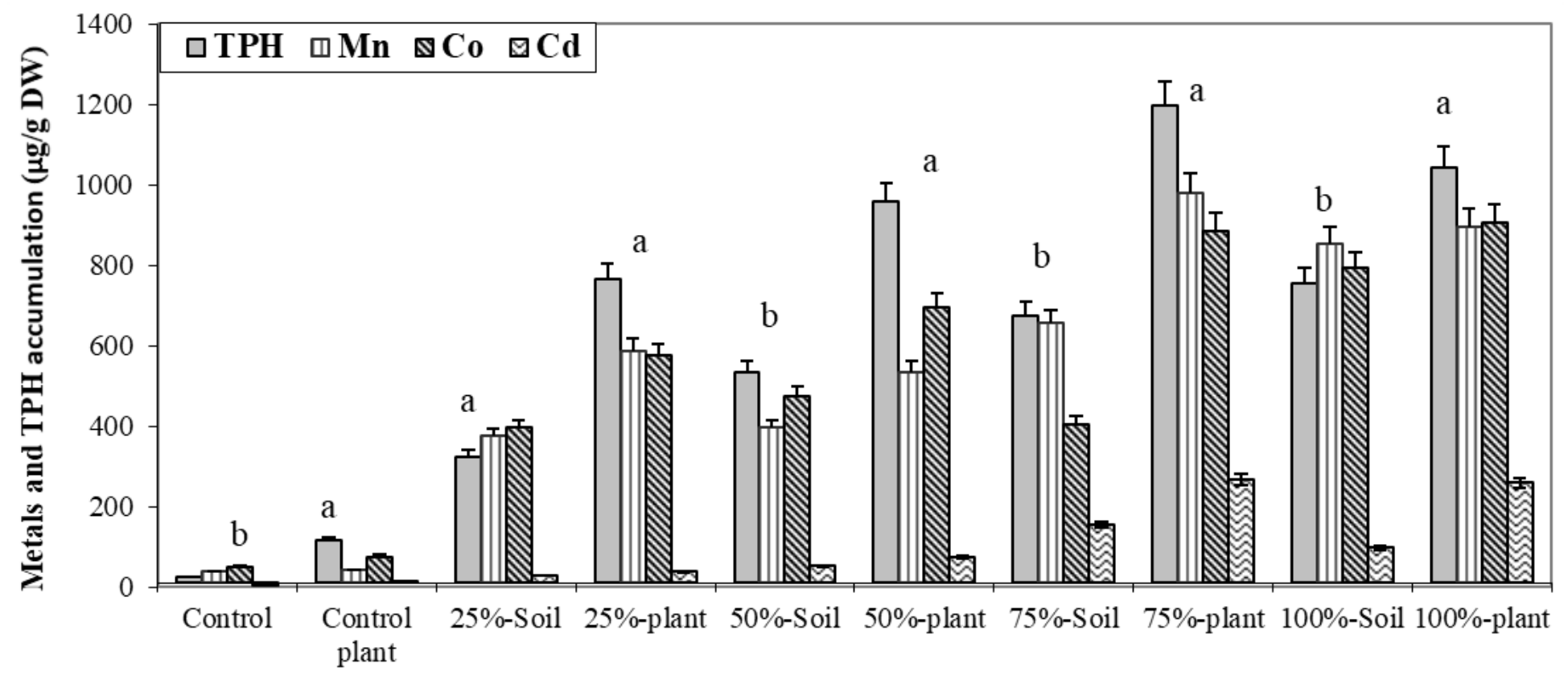

Plants irrigated with petroleum secondary effluent

Figure 1

Accumulation of metals and TPH ( $\mu \mathrm{g} / \mathrm{g}$ dry weight-DW) in Typha latifolia $\mathrm{L}$. growing on petroleum secondary effluent (PSE) with various dosing concentrations effluent concentrations 25, 50, 75 and 100\% and $(0=$ control). Different letters (a- strongly significant and b- lower significant) mean significant differences between treatment and control at a part of plant, error bars indicate the standard error of individual measurements $(n=3)$ 

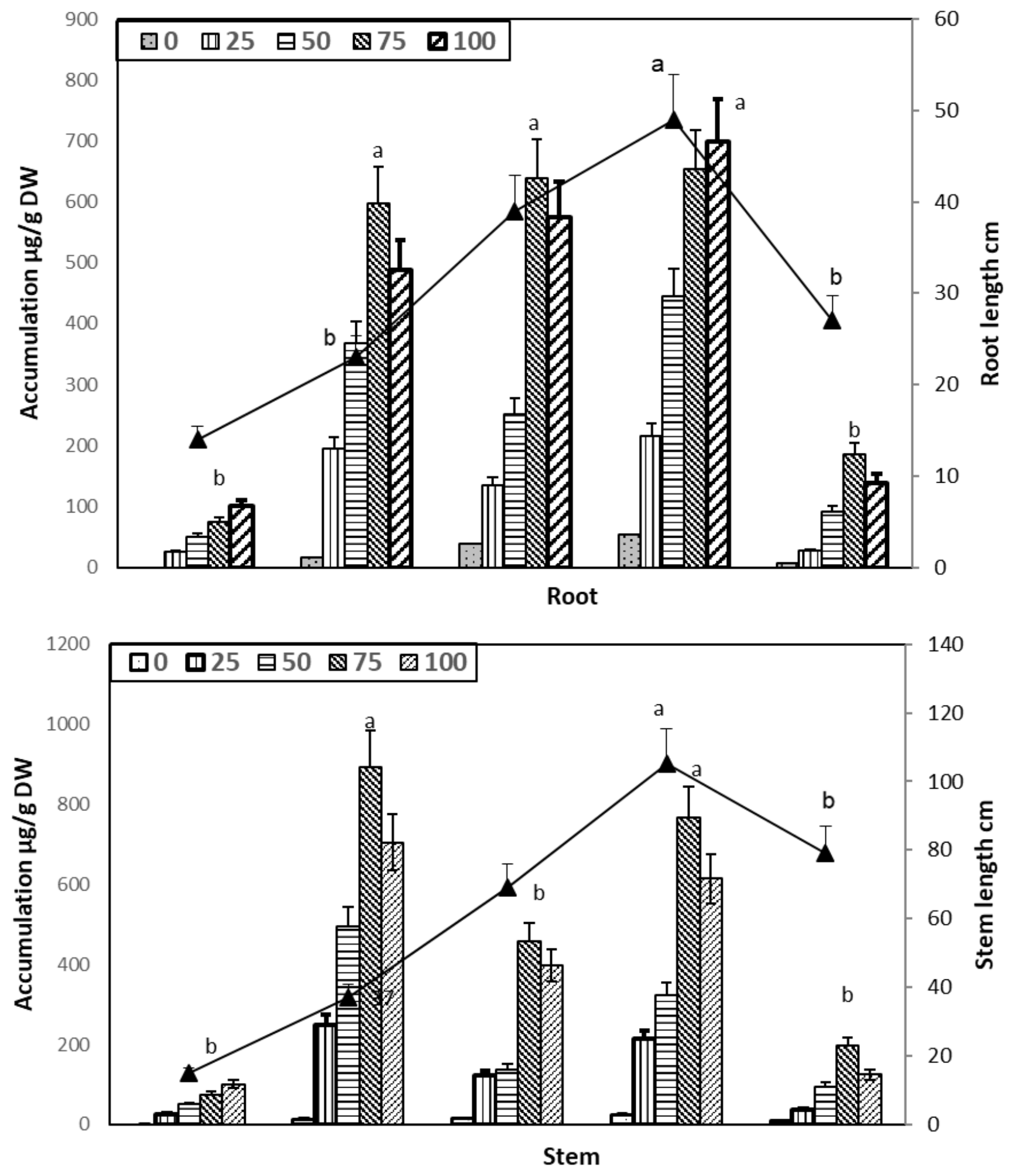

Figure 2

Accumulation of metals and TPH ( $\mu \mathrm{g} / \mathrm{g}$ dry weight-DW) in root, stem of Typha latifolia L. growing on petroleum secondary effluent concentrations $25,50,75$ and $100 \%$ and $(0=$ control). Different letters (astrongly significant and b- lower significant) mean significant differences between treatment and control at a part of plant, error bars indicate the standard error of individual measurements $(n=3)$ 


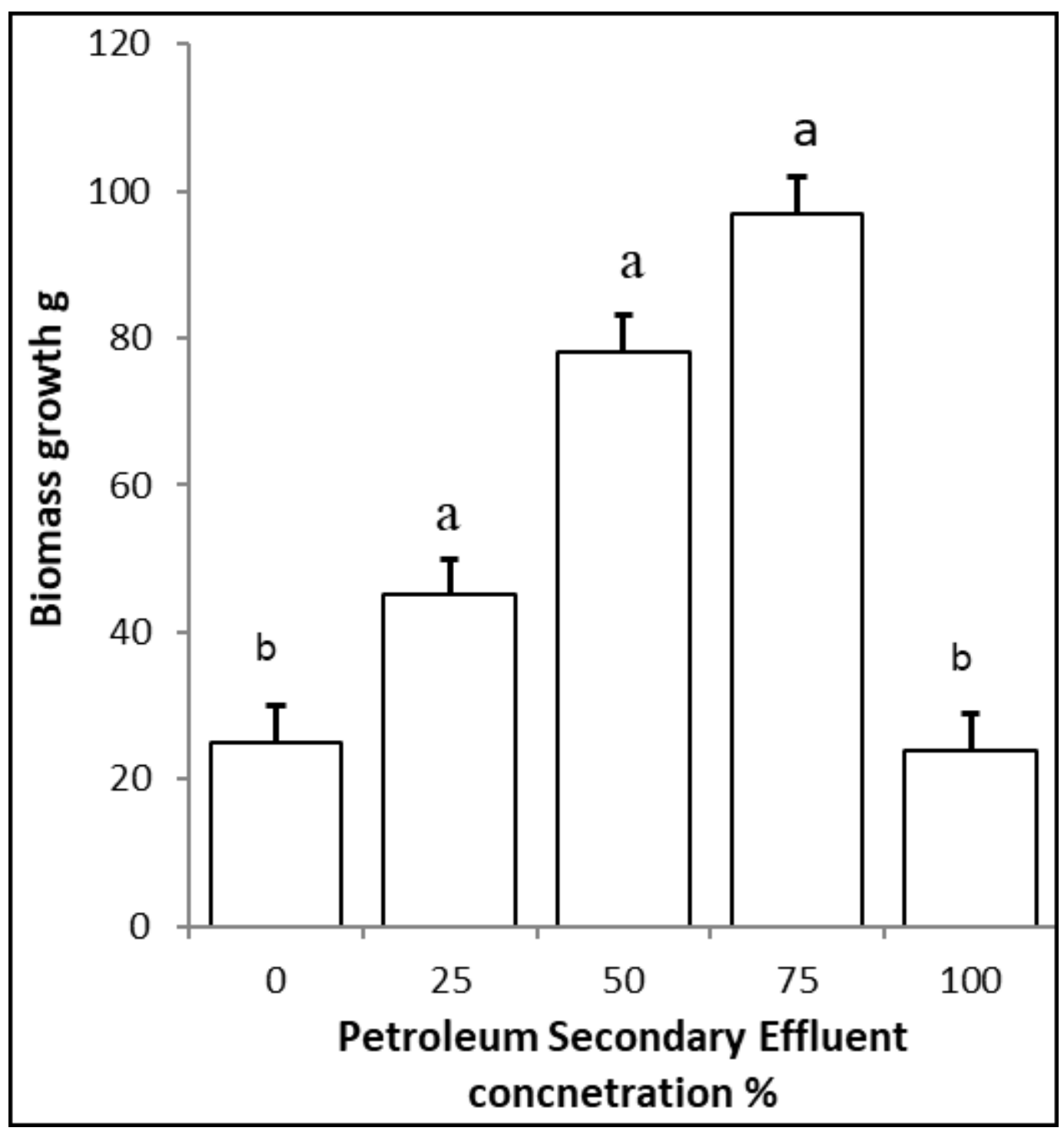

Figure 3

The biomass raised g dry weight-DW at different dosing concentration of Typha latifolia L. growing on petroleum secondary effluent concentrations $25,50,75$ and $100 \%$ and $(0=$ control). Different letters (astrongly significant and b- lower significant) mean significant differences between treatment and control at a part of plant, error bars indicate the standard error of individual measurements $(n=3)$ 


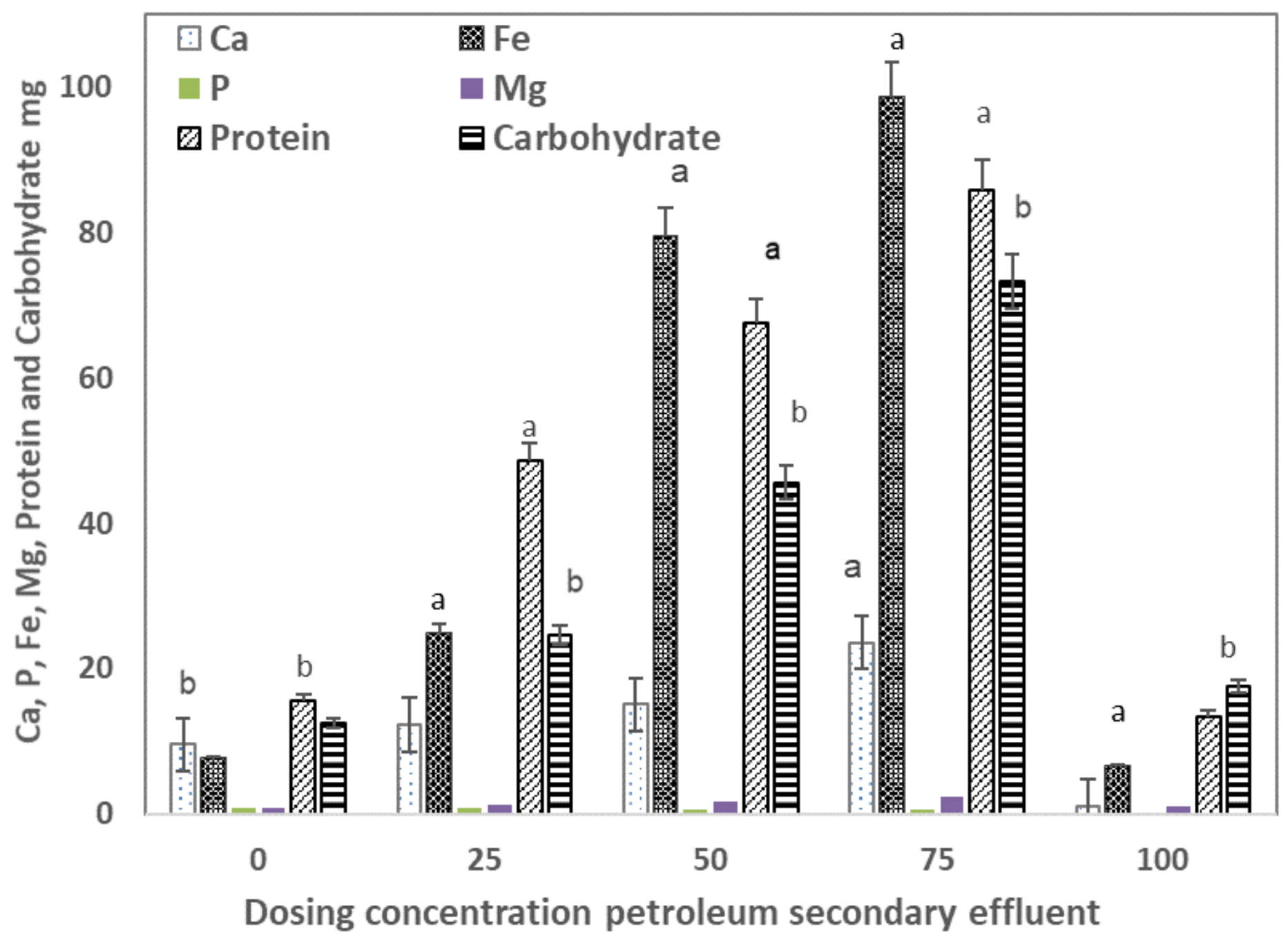

Figure 4

Micronutrients, $\mathrm{Ca}, \mathrm{P}, \mathrm{Fe}, \mathrm{Mg}$, Protein and Carbohydrate concentrations mg dry weight in plants of Typha latifolia L. growing on petroleum secondary effluent concentrations $25,50,75$ and $100 \%$ and ( $0=$ control). Different letters (a-strongly significant and b- lower significant) mean significant differences between treatment and control at a part of plant, error bars indicate the standard error of individual measurements $(n=3)$ 


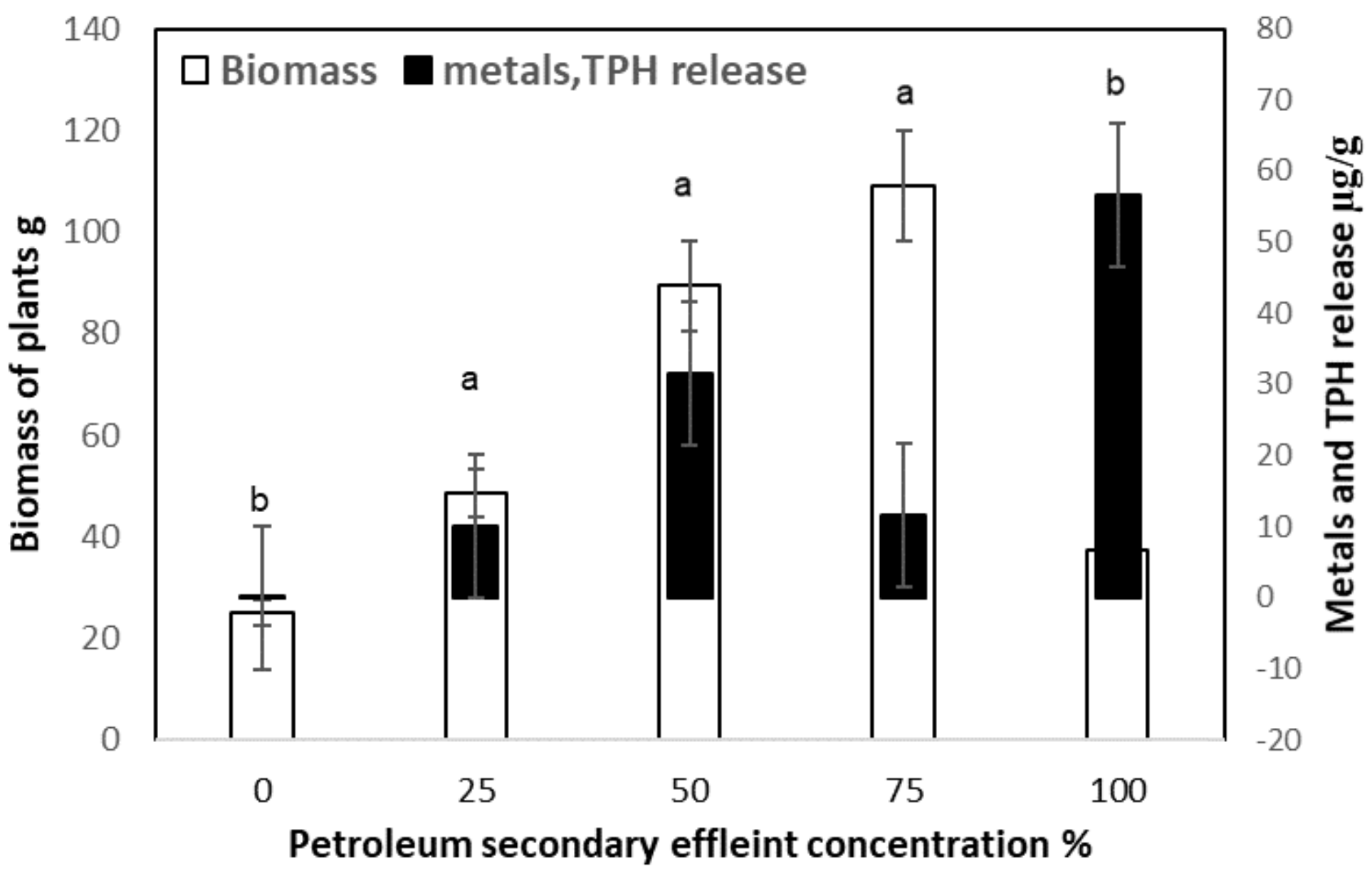

Figure 5

Metals and TPH release or precipitates in water soil $\mu \mathrm{g} / \mathrm{g}$ correlated with plant Typha latifolia $\mathrm{L}$ biomass g growing on petroleum secondary effluent concentrations $25,50,75$ and $100 \%$ and $(0=$ control). Different letters (a-strongly significant and b- lower significant) mean significant differences between treatment and control at a part of plant, error bars indicate the standard error of individual measurements $(n=3)$

\section{Supplementary Files}

This is a list of supplementary files associated with this preprint. Click to download.

- GraphicalAbstract.docx 